\title{
The Role of a Policy in Strengthening Corporate Social Responsibility: An Empirical Study of the Mining Sector in Ghana
}

\author{
Alphonse Kumaza ${ }^{1} \&$ Yuanqiong $\mathrm{He}^{1}$ \\ ${ }^{1}$ School of Management, Huazhong University of Science \& Technology, Wuhan, China \\ Correspondence: Alphonse Kumaza, Huazhong University of Science \& Technology, 1037 Luo Yu Road, \\ Hongshan District, Wuhan City, Post No.: 430074, Hubei Province, China. Tel: 86-131-2513-9179. E-mail: \\ getalphonse@gmail.com; kumaza1@yahoo.com
}

Received: March 22, 2018

doi:10.5539/jsd.v11n3p176

\author{
Accepted: April 17, $2018 \quad$ Online Published: May 30, 2018 \\ URL: https://doi.org/10.5539/jsd.v11n3p176
}

"CSR: Evolution to Survive in Developing World", GSR originally established a philosophy for CSR, which services are to be provided in an informal manner....offering a piece of infrastructure based on Community Affairs Manager's opinion of what is required in major stakeholder communities" (Golden Star Resources, Ghana).

\begin{abstract}
The prohibition imposed on resource-rich nations by the Global North governments to legislate laws to control multi-national enterprises has hit a death nail in any attempt(s) to innovate corporate social responsibility. Consequently, a self-commitment strategy was recommended for adoption to guide business own activities. This strategy undermines business participation in effective social governance yet encourages externalisation of the corporate cost of production, leading to catastrophic ramifications for host communities. The paper, therefore, proposes a policy nuance, which is a novelty in the existing literature, to oversee social responsibility undertakings and brings on board the corporate body in the social development discourse. Meanwhile, an SPSS analysis shows a statistically significant $\mathrm{p}$-value and a negative coefficient which indicates comparability between policy and corporate social responsibility resulting in an endorsement of the paper's proposition. Conclusively, a policy distinction would ensure appropriate planning, realistic and objective target setting, and compensatory plus effective and efficient implementation of basic social amenities, while systematising and normalising social agenda in corporate management strategies. It would also inspire checks of multi-national enterprises' commitments since benchmarks are established and visible for references. Expectedly, further study on an appropriate policy enforcement mechanism for social (and environmental) governance is recommended.
\end{abstract}

Keywords: corporate social responsibility, governance, Ghana, policy, self-commitment

\section{Introduction}

\subsection{Background}

That the activities of mining multi-national enterprise (MNEs) have negatively impacted livelihoods and communities without adequate safeguards presents a worrying phenomenon. A study conducted by PricewaterhouseCoopers reveals that mining MNEs gained from a whopping $1,900 \%$ of net profits spanning 2002 and 2007 yet this windfall did not benefit the owners (mostly Africa countries) of the mineral resources. Also, a body of studies has questioned reliability of social interventions planned for host communities (Frynas, 2005) using cost and benefit analysis to excuse mining negative ramifications (Jenkins \& Unies, 2001) and the destructive impact of Greenfield investment on land mass, leading to exacerbation of livelihoods (Clapp, 2005); (JA \& Daly, 1993).

Though the equity disequilibrium existing between corporate profits and community's needs is still unbalanced, the self-commitment, as a delivering system for these social development outcomes, is indeed ineffective too. Undoubtedly, the argument that the content of social giving of late is not even strategic and, more often, ineffective for philanthropy (Porter \& Kramer, 2002) holds. Besides, evidence abounds that enterprises spending for charity skyrocketed from an estimated $\$ 125$ million in 1990 to $\$ 830$ million in 2002 in the US, yet the large chunk went for advertisement meant to highlight companies' good deeds and image (p.29). Phillip Morris Companies spent $\$ 75$ million in 1999 on benevolent activities and then allocated $\$ 100$ million for promotional 
purposes (p. 29).

Meanwhile, MNEs system of governance to influence CSR through policy sphere is circumscribed by a corporate insatiable desire for profits and rent-seeking. While some studies focused attention on issues, including little impacts of commitments on host communities (Frynas, 2005), others dwelled on cost and benefit analysis (Jenkins \& Unies, 2001), with an overwhelming concentration of the literature on mining social cost implications (Halsey, Ridge, Heath, \& Halsey, 1993; Veiga \& Beinhoff, 1997; Warhurst \& Noronha, 1999; Warhurst, 1994). Likewise, studies explored CSR effects on business financial performance vice versa (Orlitzky \& Swanson, 2008), yet no research exists for a policy framework for CSR governance and this, therefore, represents the gap to fill.

The policy lack for CSR causes ineffectiveness in initiatives for host communities, and, therefore, represents the central task of the investigation. The specifics include a) policy underpinning of the current self-commitment, b) adequacy of self-commitment mechanism to address mining effects on stakeholder communities, and c) sufficiency of steps to redress mining cost to host communities. The motivation for a CSR policy, among others, is to mainstream social (and environmental) governance agenda in management strategies to avoid management biases and idiosyncrasies.

Foremost, secondary information provided baseline knowledge for primary data gathering, and are sourced from regional, national and global online information systems, while primary data was gathered through focused interviews and causal case study research.

A company-level data was obtained together with similar information from representatives of stakeholders and other institutions of the study with the sole aim of cross-referencing the mining multi-national enterprises' data provided. A questionnaire development, as the next stage, ensued, followed by its administration to the targeted research population and/or audience. The questionnaire survey results were analysed by SPSS Spearman's correlation statistical package.

\subsection{Definition of a Policy}

In a general term, a policy is decisions and statements that are taken by persons in authority, be they public or private, and processed into formal rules for implementation. Nonetheless, the term policy has attracted varied and scholarly definitions. It is generally considered as a comprehensive course of action (Smith, 1976) or interconnected decisions (Hill, 1997) or thoughts, objectives, principles underlying an organisation (Agbor, 2016) and a powerful instrument for executing plans, strategy, and control (Rue \& Ibrahim, 1998), while clearly dictating long-term strategies of an organisation.

Moreover, a policy determines directives that envision organisation's strategy and its implementation (Thompson \& Strickland, 1992). More specifically to a business, a policy is considered an indirect and a general guide, setting up limits and direction, allocates resources, determines management quality and/or ability to achieve objectives, enables proper management relations and guides actions or thinking (Bertino, Lin, Lobo, \& Rao, 2011). In a related development, policy describes decisions that shape an organisation's future. It is also a purposeful selection of tasks to be accomplished among competing interests for any circumstances in an organisation (Kozami, 2002). In the main, policy captures goals, while serving as a fulcrum around which organisational vision and statement revolve and facilitates business performance, image, and responsibility.

\subsection{Defining Multi-national Enterprises}

The proliferation of multi-national enterprises is rooted in finance availability and its easy transferability to another country. In addition, cheap labour supply elsewhere lubricates the bolts of multi-nationals development coupled with raw materials proximity to plants for purposes of agglomeration. Among the gains to enjoy are scale economies, agglomeration of markets and technology diffusion.

MNEs are, therefore, firms which produce commodities worldwide, seeking least-cost location, maximising profits, and continuously innovate through research, leading to strategic ideas - which broadly encompasses technology, innovation in production, and novel business approaches. Likewise, ownership, management, strategy, and structure are key characteristics of MNEs (Root \& Root, 1994) stressing that enterprises can be multi-national if the ownership is of different nationalities, suggestive of a British and a Dutch-owned Unilever and Shell conglomerates instances. More so, for an enterprise to be called a multi-national, managers and/or CEOs must be citizens and that qualifies them to occupy positions in enterprise's country-of-origin.

Usually, the headquarters staff is from enterprise's country and the business strategy adopted includes global profit maximisation, which is normally influenced by enterprise's parent country-of-origin, plus strategies typical of affiliate countries. Most often, promising multi-national enterprises utilise the mixed strategy of world-orientation 
but adaptable to local market conditions.

Franklin Root, therefore, defines an MNE as a mother company (whose activities transcend national boundaries) which produces commodities from a different country through its several branches via direct decisions made by affiliate firms and enterprises, implements trans-national business strategies, marketing, finance, and staffing. Moreover, most multi-nationals owe little commitment to countries they are incorporated.

For instance, Barilla, a wheat purchasing enterprise buys this product through its enterprise's branches in several other countries, including Greece, France, Germany, Norway, US, and Mexico. Furthermore, MNEs are entities in several different countries, and implement decisions, adopt clear and comprehensive strategies through their different strategic planning offices, which are separate though, and are connected via common governance regimes coherently harmonised to enable resource accruals (Armstrong, 2005). Meanwhile, it is noted that for an enterprise to internationalise the enterprise's core business policies and culture, host countries' operating environment and legal circumstances (Deresky, 2008) are key considerations. A distinction is, therefore, made contrasting 'portfolio' investment with multi-national enterprises that the former does not control or claim ownership of a party yet the latter does (Dunning, 1999), which leads Markusen to itemise three conditions, including ownership, location, and internalisation (hence "OLI" framework), that must exist for an enterprise to operate (Markusen, 1995).

\subsection{Corporate Social Responsibility Construct}

Social responsibility of a business (also known as corporate social responsibility) is an evolving concept, mutating its forms and attributes, posing universal definitional headaches. A single study identifies thirty-seven (37) definitions (Dahlsrud, 2008) apart from those emanating from academically derived constructs with methodological identification problems (Carroll, 1999). However, the definition of Carroll is widely used and referenced in many publications on CSR discourse (Carroll, 1979).

The publication of the landmark book, "Social Responsibilities for Businessman" arguably begins the modern literature on the subject of CSR (Bowen, 1953), indicating that no businesswoman existed or at least acknowledged in formal writings. Bowen believes that corporate objectives pursuance necessarily affects people's lives, society, and communities, and as such business must plan for those needs, values, and aspirations. This early definition undoubtedly provides a pathway for contemporary definitions and makes Davis famous in establishing harmony between corporate power and social responsibility.

Meanwhile, the only definition that has surfaced and recurred in many discussions of CSR with the universal application is that of Carroll's, which categorises four responsibilities, specifically, economic, legal, ethical and discretionary, for a business and stresses their equal importance in promoting the good image of conglomerates in society (Carroll, 1979).

The view that the enterprise operates in different industries that span a breadth of markets, conducts research, develops the test, and manufactures eclectic products and services, and its presence, growth fluctuations, and practices affects many people and communities supports the claim that business must embrace CSR with a view to compensating the external stakeholder constituencies.

\section{Methods}

\subsection{Source of Data}

The secondary data, which was obtained from regional, national and global sources through an online information system, provided the basic knowledge for the primary data gathering. Collection of this data was done by visiting the mines sites and the offices of the selected mining multi-national enterprises to conduct interviews and solicit relevant data on the study's subject matter. Additionally, representatives of host communities and community-based environmental institutions were identified and interviewed for firsthand information on prospecting activities by multi-national enterprises. This individual-level data was only helpful in cross-referencing and validating the company-level data for credibility.

\subsection{Data Collation}

To begin with, interviews with thirty (30) representatives of the three mining MNEs plus fifty (50) participants from the communities were conducted aimed at soliciting information regarding mining ramifications for life and property. The interviews with communities' participants merely enabled the investigation to cross reference the company-level data for accuracy. Prepared sample questions guided the mode of questioning during the interview. 


\subsection{Data Analysis}

The field data was used to design a questionnaire (to be provided on demand) and served to a targeted audience in Ghana. In all, the investigation administered fifty (50) questions but forty (40) returned answered. This data was subsequently analysed via a Spearman's correlation statistical method and the findings would authenticate and further the course of CSR policy argument. It would also institutionalise and normalise CSR policy in the overall corporate management strategy.

\subsection{Reasons for Selecting Three Mining MNEs}

The selection of the three mining MNEs was done to ascertain a point that MNE with affiliates spread across countries complies with CSR better than others which are without affiliates and in a country. Thus, the selection of Goldfields (with affiliates in South Africa, Peru, and Australia) and Asanko Gold and Golden Star Resources satisfies the condition for the investigation.

\section{Results}

\subsection{Assessment of Quality Criteria for Measures}

\subsubsection{Demographic Variables}

Table 1. Descriptive analysis of demographic variables

\begin{tabular}{llcc}
\hline Characteristics & Sub Level & Frequency & Percentage \% \\
\hline Gender & Male & 17 & 42.5 \\
& Female & 23 & 57.5 \\
Age & $41-50$ & 37 & 92.5 \\
Marital Status & $51-60$ & 3 & 7.5 \\
& Married & 29 & 72.5 \\
Education & Single & 11 & 27.5 \\
& University & 18 & 45.0 \\
\multirow{3}{*}{ Position } & Graduate School & 17 & 42.5 \\
& Post Graduate School & 5 & 12.5 \\
Period of Work & Branch Manager & 18 & 45.0 \\
& President Corporate Affairs & 22 & 55.0 \\
Business ID & $1-10$ & 22 & 55.0 \\
& $11-20$ & 18 & 45.0 \\
& Mining & 33 & 82.5 \\
\hline
\end{tabular}

Table 1 shows a synthesis of respondents' demography which includes $(n=23) 57.5$ percent of female and $(n=$ 17) $42.5 \%$ of male in the entire population. The respondents' age groups involve $41-50(\mathrm{n}=37,92.5 \%)$ and $51-60$ $(\mathrm{n}=3,7.5 \%)$ which demonstrate maturity of respondents (Awunyo-Vitor and Mbawuni 2015) to give accurate responses. Marital status of respondents are 72.5\% $(n=29)$ married and 27.5\% $(n=11)$ unmarried.

The educational qualifications of the respondents are as follows; $45.0 \%(\mathrm{n}=18)$ hold Bachelor degree, $42.5 \%(\mathrm{n}$ $=17)$ obtain Master degree, and $12.5 \%(\mathrm{n}=5)$ acquire Postgraduate degree. The positions they hold in their respective enterprises include Branch Manager $(45.5 \%, \mathrm{n}=18)$ and President, Corporate affairs $(55.0 \%, \mathrm{n}=22)$. The period of work spans $1-10$ and $11-20$ years, while $55.0 \%(\mathrm{n}=22)$ and $45.0 \%(\mathrm{n}=18)$ respectively work within the period stated. To obtain a balanced data, mining services companies are also surveyed and accounted for only $17.5 \%(n=7)$, while $82.5 \%(n=33)$ represents respondents for mining multi-national enterprises.

\subsubsection{Cross-Tabulation and Chi-Square Analyses}

Cross-tabulation (or contingency table) analysis is constructed of categorical dimensional variables to show respondents' unique characteristics as defined in the cells. It also shows relationships and interactions between variables in the table; making the measurement important social sciences methodological investigative tool. The 
cells of cross-tabulation describe percentages, while the essence of cross-tabulation analysis is to validate and support the study's questionnaire as a foundation for the analysis.

The constructs as identified are CSR and Policy. In row percentages, $37.5 \%$ agreed that CSR and Policy are related and $62.5 \%$ agreed that the constructs are related, summing up to $100 \%$ of the row total. Meanwhile, $17.6 \%$ and $100 \%$ strongly agreed respectively that CSR and Policy are related. In the corresponding third column of 13 counts, $82.4 \%$ also agreed that CSR and Policy share an association, making $100 \%$ in total.

An overwhelming $100 \%$ of the 5 counts agreed that CSR and Policy are related, producing a logical $0 \%$ in the column for 13 counts, summing up to $100 \%$ in the total column. This, therefore, confirms that the questionnaire is supported and when replicated repeatedly in an experiment same conclusions would be reached.

Table 1. Cross-tabulation for corporate social responsibility-policy

\begin{tabular}{|c|c|c|c|c|c|}
\hline \multirow{2}{*}{\multicolumn{2}{|c|}{ Corporate Social Responsibility }} & \multicolumn{3}{|c|}{ Policy } & \multirow[t]{2}{*}{ Total } \\
\hline & & 16.00 & 24.00 & 27.00 & \\
\hline \multirow[t]{4}{*}{5.00} & Count & 3 & 0 & 5 & 8 \\
\hline & Expected Count & 3.4 & 3.6 & 1.0 & 8.0 \\
\hline & $\%$ within CSR total & $37.5 \%$ & $0.0 \%$ & $62.5 \%$ & $100.0 \%$ \\
\hline & $\%$ within POL total & $17.6 \%$ & $0.0 \%$ & $100.0 \%$ & $20.0 \%$ \\
\hline \multirow[t]{4}{*}{8.00} & Count & 0 & 11 & 0 & 11 \\
\hline & Expected Count & 4.7 & 5.0 & 1.4 & 11.0 \\
\hline & $\%$ within CSR total & $0.0 \%$ & $100.0 \%$ & $0.0 \%$ & $100.0 \%$ \\
\hline & $\%$ within POL total & $0.0 \%$ & $61.1 \%$ & $0.0 \%$ & $27.5 \%$ \\
\hline \multirow[t]{4}{*}{13.00} & Count & 14 & 0 & 0 & 14 \\
\hline & Expected Count & 6.0 & 6.3 & 1.8 & 14.0 \\
\hline & $\%$ within CSR total & $100.0 \%$ & $0.0 \%$ & $0.0 \%$ & $100.0 \%$ \\
\hline & $\%$ within POL total & $82.4 \%$ & $0.0 \%$ & $0.0 \%$ & $35.0 \%$ \\
\hline \multirow[t]{4}{*}{15.00} & Count & 0 & 7 & 0 & 7 \\
\hline & Expected Count & 3.0 & 3.2 & .9 & 7.0 \\
\hline & $\%$ within CSR total & $0.0 \%$ & $100.0 \%$ & $0.0 \%$ & $100.0 \%$ \\
\hline & $\%$ within POL total & $0.0 \%$ & $38.9 \%$ & $0.0 \%$ & $17.5 \%$ \\
\hline \multirow[t]{4}{*}{ Total } & Count & 17 & 18 & 5 & 40 \\
\hline & Expected Count & 17.0 & 18.0 & 5.0 & 40.0 \\
\hline & $\%$ within CSR total & $42.5 \%$ & $45.0 \%$ & $12.5 \%$ & $100.0 \%$ \\
\hline & $\%$ within POL total & $100.0 \%$ & $100.0 \%$ & $100.0 \%$ & $100.0 \%$ \\
\hline
\end{tabular}

Note: $\mathrm{CSR}=$ Corporate Social Responsibility, $\mathrm{POL}=$ Policy

Table 3 shows a chi-square statistic $60.588^{\mathrm{a}}$ and a $\mathrm{p}<.001$. This value is still statistically significant at $5 \%$ level. This also means that CSR and Policy are related and, therefore, validates and supports the study's proposition.

Table 2. Chi-square tests

\begin{tabular}{lcc}
\hline \multicolumn{1}{c}{ Statistic } & Value & df \\
\hline Pearson Chi-Square & $60.588^{\mathrm{a}^{*}}$ & 6 \\
Likelihood Ratio & $68.048^{*}$ & 6 \\
Linear-by-Linear Association & $5.688^{* *}$ & 1 \\
\hline
\end{tabular}

Note: ${ }^{*} p<.001,{ }^{* *} p=.017$ (2-tailed); ${ }^{\text {a }} 10$ cells $(83.3 \%)$ have expected count less than 5 . The minimum expected count is .88 . 


\subsubsection{Reliability Statistics}

Table 4 shows computed reliability statistic test for the study' questionnaire. The test determines the internal consistency of a questionnaire. Since an interval consistency value more than 0.6 is accepted (Malhotra, Kim, \& Agarwal, 2004), the statistic test values for CSR (.916) and Policy (.925) are recommended excellent coefficients (George \& Mallery, 2003), thereby making the questionnaire consistent, highly reliable, and supportive of inferences or generalisation. This also makes the constructs (CSR and POLICY) a suitable validation for the study's proposition.

Table 4. Reliability statistics for questionnaire

\begin{tabular}{lccc}
\hline \multicolumn{1}{c}{ Scale } & Cronbach's Alpha & $\begin{array}{c}\text { Cronbach's Alpha Based on } \\
\text { Standardized Items }\end{array}$ & N of Items \\
\hline CSR & .916 & .933 & 4 \\
POLICY & .925 & .937 & 7 \\
\hline
\end{tabular}

\subsubsection{Descriptive Statistics}

Table 5 shows standard deviations $(S D)$ and the mean scores $(M)$ for CSR and Policy for the observation $(\mathrm{N}=40)$. Generally, a small or big dispersion of $S D$ over $M$ indicates little or big inconsistency there is between variables.

Specifically to the CSR, the little dispersion of $S D$ over $M$ shows an insignificant variability and supports the validity argument that consistency is the correlation of a construct with itself (Lockhart \& Stephens, 1998).

Similarly, the insignificant dispersion of $S D$ over $M$ for Policy is negligibly little and, therefore, shows a small variability, indicating a general increase in strength of Policy to improve CSR performance.

Table 5. Descriptive statistics for CSR \& POLICY $(\mathrm{N}=40)$

\begin{tabular}{lrr}
\hline \multicolumn{1}{c}{ Constructs/Item } & $M$ & \multicolumn{1}{c}{$S D$} \\
\hline Corporate Social Responsibility & & \\
CSR \& business unrelated & 2.1500 & .94868 \\
CSR as corporate charity & 2.8500 & 1.27199 \\
CSR depends on profits & 2.9250 & 1.18511 \\
Gap between promised \& delivered & 2.4500 & .63851 \\
Policy & & \\
Policy improves self-commitment CSR & 4.1250 & .33493 \\
Self-commitment without policy is ineffective & 3.1500 & 1.00128 \\
Policy delivers CSR efficiency & 3.5750 & .50064 \\
Policy absence discourages CSR & 3.1500 & 1.00128 \\
Policy for CSR increases its performance measurement & 3.1500 & 1.00128 \\
Policy non-existence attracts CSR carelessness & 2.2500 & .66986 \\
Policy is different from Charter & 1.5750 & .50064 \\
\hline
\end{tabular}

Note: $M=$ Mean, $S D=$ Standard Deviation

Table 6 contains a statistic for the CSR and Policy for the observation ( $\mathrm{N}=40)$. It also shows standard deviation $(S D)$ and the mean scores $(M)$. There is an insignificant spread of $S M$ over $M$, which indicates little variability for CSR. Likewise, the little dispersion of $S D$ over $M$ shows a small inconsistency for Policy. This, therefore, makes the constructs (CSR and Policy) highly comparable. 
Table 6. Descriptive statistic for group total $(\mathrm{N}=40)$

\begin{tabular}{cccc}
\hline Group Total & Mean & Std. Deviation & $\mathrm{N}$ \\
\hline CSR total & 10.3750 & 3.71889 & 40 \\
POL total & 20.9750 & 4.43464 & 40 \\
\hline
\end{tabular}

Note: $M=$ Mean, $S D=$ Standard Deviation

\section{Discussion}

\subsection{Goldfields Ghana Limited}

Goldfields Ghana acquired a concession right in 1992 in what was previously a State Corporation. Instead of underground (closed) mining (which was used under the erstwhile State Corporation) at Tarkwa and Damang, Goldfields undertakes an open-pit mining at its two mines.

\subsubsection{Economic Contribution}

Goldfields Ghana undertakes community empowerment drive to fulfill its CSR obligations. The method adopted agrees with "economic multipliers" concept espoused by the International Business Leaders Forum (Nelson, 2003) which emphasises concrete and verifiable development in stakeholder communities in the area of employment-generation through projects. Other investment zones include agriculture, education, health, water, and sanitation, plus infrastructure. Table 7 shows the enterprise's financial outlay for its stakeholder communities in 2014 and 2015.

Table 7. Statistics of goldfields Ghana CSR initiatives

\begin{tabular}{lllr}
\hline Mine & Year & Areas of CSR Initiatives & Value (US\$) \\
\hline Damang & 2014 & Education & $129,789.14$ \\
& & Health & $20,474.84$ \\
& Water \& Sanitation & $53,063.81$ \\
& Sustainable Livelihoods & $46,406.00$ \\
& Community Development - Inauguration, Publicity \& Donations & $13,350.00$ \\
& \multirow{2}{*}{2015} & Totals & $263,083.79$ \\
& Continuing Support for Scholarship \& Bursary Beneficiaries & $16,835.73$ \\
& Scholarship \& Bursary Beneficiaries, 2016 & $1,784.35$ \\
& Teacher Support & $22,356.40$ \\
& Provision of Classroom Furniture for a School & $8,478.53$ \\
& Community Training Programmes & $41,694.99$ \\
& Community Water Projects & $65,692.74$ \\
& General Administration & $28,462.71$ \\
& Total & $202,140.71$ \\
& Education & $337,115.69$ \\
& Health & $8,355.07$ \\
& Water \& Sanitation & 733.33 \\
& Sustainable Livelihoods & $529,924.46$ \\
& Infrastructure & $398,350.52$ \\
& Community Development - Inauguration, Publicity \& Admin. & $13,120.83$ \\
& Total & $1,286,866.57$ \\
& Education & 467,200 \\
& Health - Community Health Programme (Radio Sensitisation) & 14,700
\end{tabular}


Water and Sanitation

Roads \& Parks

Others - SEED Programme, Donation, Publicity \& Relationship

Proximity Assessment (Constituency for the study)

Total

$1,014,300$

Source: Goldfields Ghana Limited, Accra Office (2016).

The modest economic contribution by Goldfields Ghana to its host communities cannot, however, be disputed, more especially when CSR interventions are designed to benefit the people. Goldfields confirmed that their continued existence hinges on development interventions undertaken for stakeholder communities (interview with David Johnson, Stakeholder Relations, West Africa, GFGL, on $26^{\text {th }}$ August 2016). It indicated that the company needs 'social licence' and this licence is development-support interventions. Goldfields intimated that "CSR keeps us in operation" and "we desire to fulfill our CSR obligations (including environmental sustainability) to remain in the mining business in Ghana".

On a specific enquiry of whether Goldfields has a policy for CSR agenda, David Johnson stated that a policy lack for CSR governance did not mean low priority for CSR objectives, and further explained that social interventions for communities remained unshakable and high on management agenda. Goldfields claims that CSR issues permeate management decisions, citing CSR committee(s) with diverse stakeholder representation as evidence.

Meanwhile, Kenneth Boabeng (Assemblyman and ex-employee of the erstwhile State Corporation) is key participants, among many others, interviewed. In his introductory remarks, Kenneth Boabeng maintained that mining activities in Tarkwa has its advantages and demerits, and argued it has commercialised the community through the opening of many banks. The increased banking activities invigorated ancillary businesses for jobs for the people.

In contrast, Kenneth Boabeng expressed his disquiet about negative ramifications of mining for life and property. He recounted how blasting of huge rocks causes cracks development in residential buildings, rampant crop failures (as chemicals and dust produced from the mines affect plants growth) resulting in soaring of food prices, use of substances in the mines has rendered rainwater unsafe and unusable and the loss of farmlands through acquisition of arable farmlands for mining operations deprives farmers of their livelihoods.

More so, Kenneth Boabeng disclosed that the more worrying scenario is the selection of a few communities to benefit from Goldfields CSR projects because it considers such areas as mines enclaves and where impacts are severest. The foregoing exposé and claims corroborate with the accounts of other participants interviewed.

\subsection{Asanko Gold, Ghana}

Asanko Gold's active commercial production of gold through open-pit mining began in 2016 to date. The mines, previously exploited, were acquired in February 2014, but only two of them are in operation at the time. These mines are in phases and include phase one mines at Nkran, Abore, Adubiaso, Asuadai, while phase two mines include the Esaase deposits plus a processing plant at Nkran. The mines and their ancillary plants are situated at Ashanti region in Ghana. Table 8 indicates the enterprise economic contributions in 2014 and 2015. 


\subsubsection{Economic Contribution}

Table 8. Asanko Gold, Ghana contribution to the economy

\begin{tabular}{|c|c|c|}
\hline \multirow[t]{2}{*}{ Direct Economic Contribution } & \multicolumn{2}{|c|}{ Value (US\$) } \\
\hline & 2014 & 2015 \\
\hline \multicolumn{3}{|l|}{ Areas of Expenditure } \\
\hline Payroll (includes taxes and benefits) & $8,794,936$ & $10,767,189$ \\
\hline Govt. Taxes (incl. VAT, import duty and licence fees) & $3,614,242$ & $31,503,759$ \\
\hline Licence Fees & 620,681 & $12,884,73$ \\
\hline Royalties & 0 & 0 \\
\hline Land and Crop Compensation & $2,011,000$ & $1,887,635$ \\
\hline Payment to Suppliers for Goods and Services & $62,599,236$ & $156,737,702$ \\
\hline Proposition of payments made to local/regional suppliers & $15,649,809$ & $38,464,356$ \\
\hline Proposition of payments made to in-country contractors & $46,949,427$ & $118,273,346$ \\
\hline Total & $140,239,331$ & $202,654,758$ \\
\hline \multicolumn{3}{|l|}{ *VAT is expected to be refunded } \\
\hline \multicolumn{3}{|l|}{ Social Contribution } \\
\hline $\begin{array}{l}\text { Investment in community assistance programmes and sustainable } \\
\text { development projects }\end{array}$ & 423,000 & 470,000 \\
\hline Number of stakeholder engagements at Obotan and Esaase & 70 & 130 \\
\hline Number of farmers who received compensation & 700 & 1,500 \\
\hline \multicolumn{3}{|l|}{ Environment } \\
\hline \multirow{2}{*}{\multicolumn{3}{|c|}{$\begin{array}{l}\text { Investment in environmental management (including AKOBEN } \\
\text { Environmental Audit Training and Internal Audit) }\end{array}$}} \\
\hline & & \\
\hline & $1,900,212$ & $1,378,034$ \\
\hline Number of non-monetary sanctions & 0 & 0 \\
\hline $\begin{array}{l}\text { Total monetary value of environmental non-compliance } \\
\text { sanctions/fines }\end{array}$ & 0 & 0 \\
\hline
\end{tabular}

Source: Asanko Gold, Ghana, Accra Office, (2016)

Apart from the economic contribution indicated, Asanko Gold also engages in other social development programmes of which it indicated constitute CSR activities. Though the company lacks a policy for CSR initiatives, community development efforts and sound environmental practices remain their high priority, the enterprise intimated.

While social interventions by the mining enterprise remain scanty and dotted in isolation, environmental permits, disclosures, and reporting are means by which the enterprise's sustainable activities are assessed (interview with Asanko Gold). This presents a big challenge because documented reports (which portray sound environmental practices) do not validate evidence of declining subsistence agriculture, quality of air and water, and continuous dislocation of mining communities' inhabitants.

The paper, therefore, regrets little supports for social accountability from some MNEs and entreats the corporate entities in the mining sector to uphold their CSR obligations because a sustainable community means a successful business, though sometimes disputed.

\subsection{Golden Star Resources Limited, Ghana}

Golden Star Resources Limited acquired mining concessions to undertake exploratory activities in Ghana at Bogoso (1999), Prestea (2001), and Wassa (2002) in Ghana. In all, the mining enterprise (including the underground mine located at Prestea, which is under refurbishment) prospects in three mines and three 
processing plants at Bogoso. GSR controls $90 \%$ shares from the concessions while 10\% goes to Ghana.

\subsubsection{Economic Contribution}

Table 9. Royalty payments in US\$ for 2014 - 2016

\begin{tabular}{|c|c|c|c|c|}
\hline Entity & Sub-Entity & 2014 & 2015 & 2016 \\
\hline OASL & OASL Overhead & 71,440 & 61,538 & 65,105 \\
\hline \multirow[t]{4}{*}{ Traditional Authority } & Wassa Fiase & 102,253 & 110,769 & 117,189 \\
\hline & Mpohor & 13,169 & 0 & 0 \\
\hline & Ahanta & 13,169 & 0 & 0 \\
\hline & Total & 128,592 & 110,769 & 117,189 \\
\hline \multirow[t]{5}{*}{ Stool Lands } & Mamponso & 127,817 & 138,461 & 146,486 \\
\hline & Mpohor & 16,462 & 0 & 0 \\
\hline & Manso & 0 & 0 & 0 \\
\hline & Prestea & 16,462 & 0 & 0 \\
\hline & Total & 160,740 & 138,461 & 146,486 \\
\hline \multirow[t]{4}{*}{ District Assembly } & Mpohor Wassa East & 281,197 & 304,615 & 322,270 \\
\hline & Tarkwa Nsuaem & 36,215 & 0 & 0 \\
\hline & Ahanta West & 36,215 & 0 & 0 \\
\hline & Total & 353,627 & 304,615 & 322,270 \\
\hline
\end{tabular}

Source: Golden Star Resources Ltd., Ghana, Accra Office (2016)

Table 10. Royalty payments in US\$ for 2014-2016

\begin{tabular}{llrrr}
\hline \multicolumn{1}{c}{ Entity } & \multicolumn{1}{c}{ Sub-Entity } & \multicolumn{1}{c}{2014} & \multicolumn{1}{c}{2015} & \multicolumn{1}{c}{2016} \\
\hline OASL & OASL Overhead & 76,094 & 84,750 & 53013 \\
Traditional Authority & Bogoso & 96,687 & 119,696 & 0 \\
& Himan & 215 & 3,526 & 47,560 \\
& Bogoso/Beppo (undefined) & 39,866 & 26,328 & 0 \\
& Adaamanso & 202 & 0 & 0 \\
& Total & & 3,000 & 47,863 \\
Stool Lands & Bogoso & 136,969 & 152,549 & 95,423 \\
& Himan & 120,859 & 149,620 & 0 \\
& Bogoso/Beppo (undefined) & 268 & 4,408 & 59,450 \\
& Adaamanso & 49,832 & 32,910 & 0 \\
& Total & 252 & 0 & 0 \\
District Assembly & Prestea Huni-Valley & 171,211 & 190,687 & 119,278 \\
& Amenfi East & 376,665 & 419,511 & 262,412 \\
& Total & 0 & 0 & 0 \\
& L & 376,665 & 419,511 & 262,412 \\
\hline
\end{tabular}

Source: Golden Star Resources Ltd., Ghana, Accra Office, (2016)

Similarly, on the issue of whether the mining conglomerate has a CSR policy, the Vice President, Corporate Affairs of Golden Star Resources indicated (in an interview) that the mining enterprise has a policy for CSR 
agenda, but failed to substantiate the claim with a hard evidence to the investigation. Therefore, the amenities undertaken for communities are informally determined by CSR committee, which includes key stakeholders. This revelation suggests that CSR objectives are largely determined by GSR, which is in support of its publication captioned "CSR: Evolution to Survive in Developing World" stating that "GSR originally established a philosophy for CSR, which was to provide informal services......offering a piece of infrastructure based on Community Affairs Manager's opinion of what was required in major stakeholder communities."

More so, GSR claims that environmental management is top on their agenda when asked about the mining giant's environmental footprint. The investigation, therefore, requested for a proof that the company's field activities information and those from brochures and other established documents are same and reflect serious sustainable mining. The research finds marked differences in field information and the company's publications programmes which are couched in futuristic terms and have little chance(s) of success.

Instances evidencing mining corporate entities lapse in real environmental management include crop failure (in communities which are hitherto productive farm enclaves), pollution and deforestation yet documentation and publications, and narratives from the media portray the niceties. This, therefore, supports the papers avowed skepticism about publications of corporate entities' intents (as contained in reports and documentation) and about their activities which are opposite of field information.

This phenomenon, unfortunately, is common in all mining trans-national enterprises and also exists in the wider corporate organisations, making environmental management unreal and difficult. This has been the sticky point; retardation of sustainable environmental efforts since corporate entities' field actions and their publications and reports are polls apart.

The succinctly crafted philosophy backing GSR CSR compliance indicates lack of seriousness and corroborates widely held notion that CSR remains public relations propaganda tool for MNEs to promote and highlight company's image and so-called good deeds. The paper's proposal for a policy for CSR to guide and evaluate commitments by mining MNEs is to reduce corporate insincerity and dishonesty while championing better governance principles and standards.

\subsection{Critical Issue}

The paper takes an issue with the policy lack for CSR governance because it facilitates ineffectiveness and inadequacy of interventions in host communities. Also, CSR is deemed to address inequality between corporate excessive profits and social development programmes since payment of corporate taxes is insufficient. More so, corporate activities aimed at high profits and rent-seeking continue without an expressed emphasis on how to make CSR deliver compensatory initiatives in and for host communities.

Whereas some MNEs consider their financial and other legal obligations as a pretext to be unperturbed and oblivious of global concerns for their deleterious activities, quite a number of enterprises strive to show their honesty in CSR undertakings and engagement.

The above notwithstanding, the paper's stance that tax and royalty payments by an MNE cannot replace social responsibility embodies an unsettled accountability toward the business operating environment; that is the CSR obligations for stakeholder constituencies. Therefore, the findings that CSR is still being used to showcase companies' good deeds and image and not to the material benefits of the host communities is staggering and unfortunate. The reason the paper proposes a policy nuance as a novel strategy that can take CSR out of the woods. Thus, CSR must address the complex social (including environmental) challenges and compensate for corporate excessive profits from the communities. 


\subsection{Non-parametric correlations for individual groups}

Table 11. Spearman's correlation matrix for corporate social responsibility, items $(\mathrm{N}=40)$

\begin{tabular}{|c|c|c|c|c|c|c|}
\hline & Items & 1 & 2 & 3 & 4 & 5 \\
\hline \multirow{15}{*}{ Spearman's rho } & \multirow{3}{*}{ CSR \& business unrelated } & 1.000 & $.760^{* *}$ & $.702^{* *}$ & $.666^{* *}$ & $.897^{* *}$ \\
\hline & & . & .000 & .000 & .000 & .000 \\
\hline & & 40 & 40 & 40 & 40 & 40 \\
\hline & \multirow{3}{*}{ CSR as corporate charity } & $.760^{* *}$ & 1.000 & $.974^{* *}$ & $.962^{* *}$ & $.946^{* *}$ \\
\hline & & .000 & . & .000 & .000 & .000 \\
\hline & & 40 & 40 & 40 & 40 & 40 \\
\hline & \multirow{3}{*}{ CSR depends on profits } & $.702^{* *}$ & $.974^{* *}$ & 1.000 & $.918^{* *}$ & $.922^{* *}$ \\
\hline & & .000 & .000 & . & .000 & .000 \\
\hline & & 40 & 40 & 40 & 40 & 40 \\
\hline & \multirow{3}{*}{ Gap between promised \& delivered } & $.666^{* *}$ & $.962^{* *}$ & $.918^{* *}$ & 1.000 & $.910^{* *}$ \\
\hline & & .000 & .000 & .000 & & .000 \\
\hline & & 40 & 40 & 40 & 40 & 40 \\
\hline & \multirow{3}{*}{ CSR total } & $.897^{* *}$ & $.946^{* *}$ & $.922^{* *}$ & $.910^{* *}$ & 1.000 \\
\hline & & .000 & .000 & .000 & .000 & . \\
\hline & & 40 & 40 & 40 & 40 & 40 \\
\hline
\end{tabular}

Note: $* *$ Correlation is significant at the 0.01 level (2-tailed), CSR $=$ Corporate Social Responsibility

Table 11 shows a correlation for CSR. Out of the overall cells, only 6 coefficients are of interest for interpretation. This shows that the diagonal contains cells comprising coefficients of themselves producing 1.000 while variables opposite the diagonal replicate themselves and, therefore, are of no prominence for discussion. Across the board, the coefficients $(.760 ; .702 ; .666 ; .974 ; .918 ; .962)$ statistically significant $(\mathrm{p}<.001,2$-tailed) excellent to strong positive comparability respectively between the variables, suggestive of linear relationships in which an increase in a variable leads to a rise in another. This is validity construct criteria (Cook, Campbell, \& Day, 1979) making the variables to support the study's propositions. 
Table 12. Correlation matrix for policy, items $(\mathrm{N}=40)$

\begin{tabular}{|c|c|c|c|c|c|c|c|c|c|}
\hline & Items & 1 & 2 & 3 & 4 & 5 & 6 & 7 & 8 \\
\hline \multirow{24}{*}{$\begin{array}{l}\text { Spearman's } \\
\text { rho }\end{array}$} & \multirow{3}{*}{ POL total } & 1.000 & $.940^{* *}$ & $.940^{* *}$ & $.940^{* *}$ & $.629^{* *}$ & $.940^{* *}$ & $.629^{* *}$ & $.940^{* *}$ \\
\hline & & . & .000 & .000 & .000 & .000 & .000 & .000 & .000 \\
\hline & & 40 & 40 & 40 & 40 & 40 & 40 & 40 & 40 \\
\hline & \multirow{3}{*}{$\begin{array}{l}\text { Policy delivers CSR } \\
\text { efficiency }\end{array}$} & $.940^{* *}$ & 1.000 & $1.000^{* *}$ & $1.000^{* *}$ & $.325^{*}$ & $1.000^{* *}$ & $.325^{*}$ & $1.000^{* *}$ \\
\hline & & .000 & . & . & . & .041 & $\cdot$ & .041 & \\
\hline & & 40 & 40 & 40 & 40 & 40 & 40 & 40 & 40 \\
\hline & \multirow{3}{*}{$\begin{array}{l}\text { Policy abs } \\
\text { discourages CSR }\end{array}$} & $.940^{* *}$ & $1.000^{* *}$ & 1.000 & $1.000^{* *}$ & $.325^{*}$ & $1.000^{* *}$ & $.325^{*}$ & $1.000^{* *}$ \\
\hline & & .000 & . & . & . & .041 & . & .041 & . \\
\hline & & 40 & 40 & 40 & 40 & 40 & 40 & 40 & 40 \\
\hline & \multirow{3}{*}{$\begin{array}{l}\text { Policy for CSR betters } \\
\text { performance }\end{array}$} & $.940^{* *}$ & $1.000^{* *}$ & $1.000^{* *}$ & 1.000 & $.325^{*}$ & $1.000^{* *}$ & $.325^{*}$ & $1.000^{* *}$ \\
\hline & & .000 & . & . & . & .041 & . & .041 & \\
\hline & & 40 & 40 & 40 & 40 & 40 & 40 & 40 & 40 \\
\hline & \multirow{3}{*}{$\begin{array}{l}\text { Policy lack attracts CSR } \\
\text { carelessness }\end{array}$} & $.629^{* *}$ & $.325^{*}$ & $.325^{*}$ & $.325^{*}$ & 1.000 & $.325^{*}$ & $1.000^{* *}$ & $.325^{*}$ \\
\hline & & .000 & .041 & .041 & .041 & . & .041 & . & .041 \\
\hline & & 40 & 40 & 40 & 40 & 40 & 40 & 40 & 40 \\
\hline & Self-commitment & $.940^{* *}$ & $1.000^{* *}$ & $1.000^{* *}$ & $1.000^{* *}$ & $.325^{*}$ & 1.000 & $.325^{*}$ & $1.000^{* *}$ \\
\hline & \multirow{2}{*}{$\begin{array}{l}\text { without policy } \\
\text { ineffective }\end{array}$} & .000 & . & . & . & .041 & . & .041 & . \\
\hline & & 40 & 40 & 40 & 40 & 40 & 40 & 40 & 40 \\
\hline & \multirow{3}{*}{$\begin{array}{l}\text { Policy improves } \\
\text { self-commitment CSR }\end{array}$} & $.629^{* *}$ & $.325^{*}$ & $.325^{*}$ & $.325^{*}$ & $1.000^{* *}$ & $.325^{*}$ & 1.000 & $.325^{*}$ \\
\hline & & .000 & .041 & .041 & .041 & . & .041 & $\cdot$ & .041 \\
\hline & & 40 & 40 & 40 & 40 & 40 & 40 & 40 & 40 \\
\hline & \multirow{3}{*}{$\begin{array}{l}\text { Policy is different from } \\
\text { Charter }\end{array}$} & $.940^{* *}$ & $1.000^{* *}$ & $1.000^{* *}$ & $1.000^{* *}$ & $.325^{*}$ & $1.000^{* *}$ & $.325^{*}$ & 1.000 \\
\hline & & .000 & . & . & . & .041 & . & .041 & \\
\hline & & 40 & 40 & 40 & 40 & 40 & 40 & 40 & 40 \\
\hline
\end{tabular}

**Correlation is significant at the 0.01 level (2-tailed)

*Correlation is significant at the 0.05 level (2-tailed).

In Table 12, similar patterns emerge where the coefficients of the diagonal are same and at all-time resulting in 1.000 and those opposite the diagonal repeat themselves, and therefore, are of no importance and cannot be reported on or interpreted.

Meanwhile, the remaining coefficients (as observed in the matrix) show statistically significant (both at $\mathrm{p}<.001$, 2 -tailed and $\mathrm{p}<.041,2$-tailed) perfect to strong positive relationship respectively between the constructs. This result also satisfies the validity construct argument (Cook et al., 1979) that a measurement taken should properly indicate the construct underlying the proposition, while a great amount of consistency creates room for understanding and reporting the construct measurement (Henson, 2001). 


\subsection{Non-parametric correlations for Group Total}

Table 13. Spearman's correlation matrix for group total $(\mathrm{N}=40)$

\begin{tabular}{|c|c|c|c|c|}
\hline \multicolumn{3}{|c|}{ Group Totals } & 1 & 2 \\
\hline \multirow{6}{*}{ Spearman's rho } & \multirow{3}{*}{ CSR total } & Correlation Coefficient & 1.000 & $-.332^{*}$ \\
\hline & & Sig. (2-tailed) & . & .036 \\
\hline & & $\mathrm{N}$ & 40 & 40 \\
\hline & \multirow{3}{*}{ POL total } & Correlation Coefficient & $-.332^{*}$ & 1.000 \\
\hline & & Sig. (2-tailed) & .036 & . \\
\hline & & $\mathrm{N}$ & 40 & 40 \\
\hline
\end{tabular}

Note: $* P=.036(2$-tailed $)$

SPSS calculation reports p-value as .036, signifying there is an evidence to believe that policy application to CSR governance would ensure efficiency in CSR initiatives, and thus makes the constructs to monotonically correlate. Similarly, Spearman's analysis showed CSR and policy comparable, indicating that a negative monotonic correlation exists where $\mathrm{r}\left(=-.332^{*}, \mathrm{n}=40, \mathrm{p}<.036,2\right.$-tailed $)$.

Effectively, the complete agreement which exists between the variables under consideration makes policy distinction, unlike the self-commitment, a viable means to inject discipline and coordination in programmes implemented for the mining communities. The comparability between the constructs confirms that predictions are highly possible and can be made.

The relationship, thus, brings to the fore a two-pronged scenario; first, it supports the proposition that a CSR policy would deliver effective and sufficient social interventions and encourage sustainable environmental objectives and second, the continuous and increased deployment of the self-commitment mechanism for CSR agenda reduces any future chance(s) for policy consideration.

It is, therefore, evident that CSR and sustainable environmental interventions, in the long-term, may be seriously undermined by corporate bodies, particularly mining MNEs for profits and rent-seeking. Deductively, it can be inferred that the non-policy self-commitment has also prevented transformation, strengthening and revolutionisation of CSR to meet contemporary exigencies.

Therefore, this finding provides an opportunity for governments and civil society groups in third world countries to experiment the paper's proposition for a policy nuance for CSR governance.

\subsubsection{Comments}

Having examined the three mining MNEs, it is noted that CSR governance (including sustainable environmental practices) is same irrespective of affiliates. The self-commitment (which is carelessly managed by most corporate entities) is prevalent in business practice (though informally applied) and to dodge public scrutiny, efforts to institutionalise and legitimise this informal system are afoot, indicating that the policy recommendation for CSR governance may be vehemently opposed.

Again, to institutionalise the self-commitment is to sustain corporate charity character of CSR, which would then insulate corporate entities from being accountable to their stakeholders. It is also noted that management's predisposition and idiosyncrasies hamper delivery of CSR interventions, particularly the complications of a policy nuance equation.

The finding that a policy for CSR would improve interventions' effectiveness and adequacy for the host communities is heartwarming and revealing. Within this logic, the paper envisages that a CSR policy would improve the certainty of interventions through compliance assessment and monitoring and evaluation. It would also ensure audit of enterprises' CSR performance leading to increased transparency and of business stewardship while influencing the corporate good image. In contrast, the continual use of self-commitment arguably would reinforce the stereotypes by making CSR an appendage of corporate affairs.

Participation of the stakeholder in the execution of social (and environmental) interventions remains a priority since policy alone is insufficient to produce positive and tangible outcomes. The much talk about environmental permits, disclosures, and reporting would continue to remain mere paperwork minus stakeholder supervision because most environmental protection agencies are unperturbed and their inertia to make follow-ups and monitor and determine the accuracy of environmental practices by MNEs is commonly observed. This behaviour 
may exhibit itself in weak technical manpower or lack of equipment to undertake monitoring operations in developing African countries.

Meanwhile, the international principles and/or guidelines on MNEs are copiously reproduced in MNEs publications yet not adhered to and/or reflect in the management culture of most corporate entities. The paper maintains that proper management of CSR can influence sustainable practices since environmental issues have broadly been classified as part of CSR practice these days.

It is noted that the present mode of CSR governance delivers little value to social development yet the externalisation of corporate cost of production continues with dire ramifications for host communities. A CSR policy, therefore, would rebalance the disequilibria between corporate benefits and social net returns. While a policy-backed self-commitment system can be intimidating, a scholarly sensitisation for corporate entities could come handy.

\subsection{Self-commitment Paradigm vis-à-vis CSR Policy}

Self-commitment and its interventions are mostly based on corporate managers' conviction and freewill or discretion, instead of purposefully planned activities emanating from a strategy. It emphasises informal, sporadic, unsystematic and irregular delivery of CSR interventions. Thus, an ad hoc, discriminatory and categorised procedure for initiatives delivers little to stakeholder communities (Hollender \& Breen, 2010).

Though little is done to address the myriad of ecological catastrophes the world had and witness in recent times, MNEs still use CSR to disguise their "irresponsible" activities leading to huge social cost (Action (Aid, 2004) result from corporate wilful and quick returns to scale. Again, the claim that MNEs operations increase ecological devastation corroborates with Visser's assertions that issues of CSR, sustainability, and ethics which have remained peripheral to business and, standards, most companies adopted, including internationally recommended regimes and sets of initiatives, guidelines, have not stopped or reduced the ever-increasing destruction of mining communities (Visser, 2011).

The apparent weakness of the self-commitment system to deliver CSR agenda has encouraged and emboldened the proposition for a policy distinction to deliver interventions in host communities. The governance system of mining MNEs has obligations to make this CSR policy nuance a reality. Therefore, if CSR is to succeed as an institution of management, a policy foundation is necessary for delivering its interventions.

Again, most MNEs fix targets for CSR and achieved them not because much effort is invested in them, rather it is, partly, due to easy targets setting. A policy-backed CSR provides room for the objective and accurate setting of targets since stakeholder participation inspires greater and well-informed CSR decisions and strategies.

The informal self-commitment provides rooms for serious setbacks as interventions are, mostly, unplanned buttressing Hawkins' skepticism about corporate leadership's sincerity with CSR agenda and as such calls for benchmarks (in this case, CSR-specific policy) for social initiatives. Hawkins further stresses that such benchmarks should be total, and balanced to prevent cynicism and stricter regulations, and assist in accountable and transparent systems to champion stakeholder aspirations (Hawkins, 2006).

More so, the policy proposal agrees with the suggestion that social responsibility for businessmen must finally be sought or situated in the actual policies it is associated with and to deliver material impacts of social interventions (Heald, 1970). Moreover, the negative ramifications of mining are not in short supply. Indeed, a body of studies implicates multi-national enterprises complicity in environmental destruction and labour exploitation dating back in history (Aid, 2004; Malan, 2005; Pakenham, 1992; Armstrong, 2005), including a shortfall in ecology, biodiversity, and water bodies (Visser, Matten, Pohl, \& Tolhurst, 2010; Visser, 2010).

Thus, multi-nationals, propelled by profit motives, have profoundly impacted negatively the environment and its resources, and quality of life.

\subsubsection{Importance of CSR Policy}

The policy for CSR agenda would direct and dictate appropriate corporate management's handling of socio-economic needs of the people and their communities. A policy would enable exact and systematic governance of stakeholder interests and also influences visibility of initiatives. By policy, excuses and oversight are avoided in interventions captured under CSR agenda. More so, a policy for CSR would allow stakeholders to cross-reference planned commitments and determine their sufficiency while keeping MNEs on their toes.

Furthermore, strategic decision-making influences core issues of business external requirements, and integrating CSR policy into business overall strategies for managing community needs is a practical reality and 
works to harmonise understanding for both business and host communities on common interests. Therefore, a policy for CSR is feasible and also increases a business' net returns and prosperity for external stakeholder constituencies.

\section{Conclusion}

The paper asserts that CSR is brutally defeated by the restriction imposed on national governments to legislate laws to control multi-national enterprises' activities. The hard law absence has, subsequently, occasioned the self-commitment recommended and successively adopted by corporate entities in meeting social needs. While this arrangement is heartwarming to start with, its shortcomings incentivise social discontent and cynicism of corporate intentions, fueling calls for a paradigm shift in social and environmental governance. Within this context, a policy distinction to guide CSR objectives is proposed for compliance by mining MNEs and other corporate entities to add value to and meet current exigencies. The arguments for this novelty is not uncommon. A policy application to social interventions promotes planning efficiency and effectiveness, certainty, systematisation of programme initiatives, accountability and transparency of corporate environmental stewardship, and above all integration and formalisation of CSR agenda in business wider strategy and management.

Generally, interview techniques were used in gathering data, and out of which questionnaire was designed and served to the research population and/or audience. The questionnaire survey results were analysed through Spearman's correlation package. The findings validate the paper's argument that a policy for CSR would elicit compensatory returns from corporate interest for host communities and other external stakeholder constituencies.

Inasmuch as CSR policy proposal remains recommendation and provisional which practice, application and compliance are to show concrete and tangible outcomes, it is anticipated that further studies are done to discover an appropriate policy enforcement mechanism suitable for social and environmental objectives.

\section{Acknowledgment}

Many thanks to you, Vice President, Corporate Affairs, Golden Star Resources, Ghana; and the President, Stakeholder Relations, West Africa, Goldfields, Ghana, for your invaluable information support during field data gathering. My heartfelt gratitude goes to Mr. Isaac Tettey for his priceless contributions. Lastly, I owe my beautiful daughter, Caitlyn Edudzi Mic-Kumaza, a debt of gratitude for enduring my absence for three years while I was in China for the Ph.D. programme. To the almighty God, I say congratulations to you for walking with me since the beginning of this long and lonely journey.

\section{References}

Agbor, S. (2016). An Appraisal of Open System Business Policy Models in the Management of Mission Hospitals in South-South Nigeria.

Aid, C. (2004). Behind the mask: the real face of CSR. London: Christian Aid.

Armstrong, E. (2005). Integrity, transparency, and accountability in public administration: Recent trends, regional and international developments and emerging issues. United Nations, Department of Economic and Social Affairs, 1-10.

Awunyo-Vitor, D., \& Mbawuni, J. (2015). Drivers of Value Added Tax Flat Rate Scheme Compliance by Traders in Kumasi Metropolis, Ghana. IUP Journal of Accounting Research \& Audit Practices, 14(2), 29.

Bertino, E., Lin, D., Lobo, J., \& Rao, P. R. (2011). Method and system for determining policy similarities: Google Patents.

Bowen, H. R. (1953). Social responsibilities of the businessman. Harper.

Carroll, A. B. (1979). A three-dimensional conceptual model of corporate performance. Academy of management review, 4(4), 497-505. https://doi.org/10.5465/amr.1979.4498296

Carroll, A. B. (1999). Corporate social responsibility: Evolution of a definitional construct. Business \& society, 38(3), 268-295. https://doi.org/10.1177/000765039903800303

Clapp, J. (2005). Global environmental governance for corporate responsibility and accountability. Global Environmental Politics, 5(3), 23-34. https://doi.org/10.1162/1526380054794916

Cook, T. D., Campbell, D. T., \& Day, A. (1979). Quasi-experimentation: Design \& analysis issues for field settings (Vol. 351). Houghton Mifflin Boston. 
Dahlsrud, A. (2008). How corporate social responsibility is defined: an analysis of 37 definitions. Corporate Social Responsibility and Environmental Management, 15(1), 1-13. https://doi.org/10.1002/csr.132

Deresky, H. (2008). International management: A cross managing borders and cultures (6th ed.). USA: Pearson.

Dunning, J. H. (1999). Trade, the location of economic activity and the multinational enterprise: a search for an eclectic approach. PJ Buckley \& P. Ghauri. The internationalization of the firm, 61-79.

Frynas, J. G. (2005). The false developmental promise of corporate social responsibility: Evidence from $\begin{array}{lllll}\text { multinational oil } & \text { companies. }\end{array}$ https://doi.org/10.1111/j.1468-2346.2005.00470.x

George, D., \& Mallery, M. (2003). Using SPSS for Windows step by step: a simple guide and reference.

Halsey, A. H., Ridge, J. M., Heath, A. F., \& Halsey, A. (1993). Origins and destinations. JSTOR.

Hawkins, D. (2006). Corporate social responsibility: balancing tomorrow's sustainability and today's profitability. Springer. https://doi.org/10.1057/9780230625815

Heald, M. (1970). The social responsibilities of business: Company and community 1900-1960. Transaction Publishers.

Henson, R. K. (2001). Understanding internal consistency reliability estimates: A conceptual primer on coefficient alpha. Measurement and evaluation in counseling and development, 34(3), 177.

Hill, M. J. (1997). The policy process in the modern state: Prentice Hall PTR.

Hollender, J., \& Breen, B. (2010). The responsibility revolution: How the next generation of businesses will win. John Wiley \& Sons.

JA, R. G., \& Daly, H. E. (1993). Poverty alleviation is essential for environmental sustainability. Environmental Economics and Pollution Division.

Jenkins, R., \& Unies, N. (2001). Corporate codes of conduct: Self-regulation in a global economy: United Nations Research Institute for Social Development Geneva.

Kozami, A. (2002). Business Policy and Strategic Management, 2e. Tata McGraw-Hill Education.

Lockhart, R., \& Stephens, M. (1998). 16 The probability plot: Tests of fit based on the correlation coefficient. Handbook of Statistics, 17, 453-473. https://doi.org/10.1016/S0169-7161(98)17018-9

Malan, D. (2005). Corporate citizens, colonialists, tourists or activists? Ethical challenges facing South African corporations in Africa. The Journal of Corporate Citizenship, (18), 49. https://doi.org/10.9774/GLEAF.4700.2005.su.00009

Malhotra, N. K., Kim, S. S., \& Agarwal, J. (2004). Internet users' information privacy concerns (IUIPC): The construct, the scale, and a causal model. Information systems research, 15(4), 336-355. https://doi.org/10.1287/isre.1040.0032

Markusen, J. R. (1995). The boundaries of multinational enterprises and the theory of international trade. The Journal of Economic Perspectives, 9(2), 169-189. https://doi.org/10.1257/jep.9.2.169

Nelson, J. (2003). Economic Multipliers: Revisiting the core responsibility and contribution of business to development. Paper presented at the International Business Leaders Forum (IBLF) Policy Paper.

Orlitzky, M., \& Swanson, D. (2008). Toward integrative corporate citizenship: Research advances in corporate social performance. Springer. https://doi.org/10.1057/9780230594708

Pakenham, T. (1992). The Scramble for Africa: White Man's Conquest of the Dark Continent. New York: HarperCollins Publishers.

Porter, M. E., \& Kramer, M. R. (2002). The competitive advantage of corporate philanthropy. Harvard business review, 80(12), 56-68.

Root, F. R., \& Root, F. (1994). Design entry strategy for international markets. Entry strategies for international markets. New York: Lexington Books, 1-24.

Rue, L. W., \& Ibrahim, N. A. (1998). The relationship between planning sophistication and performance in small businesses. Journal of small business management, 36(4), 24.

Smith, B. C. (1976). Policy-making in British government: An analysis of power and rationality. Rowman \& Littlefield Publishers, Incorporated. 
Thompson, A. A., \& Strickland, A. J. (1992). Strategic management: concepts and cases. McGraw-Hill/Irwin.

Veiga, M., \& Beinhoff, C. (1997). UNECA centers: A solution to reduce mercury pollution from artisanal gold mining activities. UNEP Industry and Environment, 20(1), 49-52.

Visser, W. (2010). The age of responsibility: CSR 2.0 and the new DNA of business.

Visser, W. (2011). The age of responsibility: CSR 2.0 and the new DNA of business. John Wiley \& Sons.

Visser, W., Matten, D., Pohl, M., \& Tolhurst, N. (2010). The A to Z of corporate social responsibility. John Wiley \& Sons.

Warhurst, A. (1994). The limitations of environmental regulation in mining. Mining and the Environment: International Perspectives on Public Policy, 133-172.

Warhurst, A., \& Noronha, M. L. (1999). Environmental Policy in Mining: Corporate Strategy and Planning. CRC Press.

\section{Copyrights}

Copyright for this article is retained by the author(s), with first publication rights granted to the journal.

This is an open-access article distributed under the terms and conditions of the Creative Commons Attribution license (http://creativecommons.org/licenses/by/4.0/). 